\title{
Lignin and fiber digestion
}

\author{
KENNETH J. MOORE AND HANS-JOACHIM G. JUNG
}

Authors are professor, Department of Agronomy, Iowa State University, Ames, Iowa 50011; and research dairy scientist, USDA, Agricultural Research Service, Plant Science Research Unit and U.S. Dairy Forage Research Center Cluster, St. Paul, Minn. 55108.

\begin{abstract}
Lignin is a polymer formed from monolignols derived from the phenylpropanoid pathway in vascular plants. It is deposited in the cell walls of plants as part of the process of cell maturation. Lignin is considered an anti-quality component in forages because of its negative impact on the nutritional availability of plant fiber. Lignin interferes with the digestion of cell-wall polysaccharides by acting as a physical barrier to microbial enzymes. Lignification therefore has a direct and often important impact on the digestible energy (DE) value of the forage. There are a number of plant-related factors that affect lignification in individual plants and plant communities. Lignification is under genetic control and there are considerable differences in lignin concentration and composition among species and even genotypes within species. Genetic differences in lignification are first expressed at the cellular level and are affected by biochemical and physiological activities of the cell. As cells differentiate, differences in lignification occur depending on the tissues and organs being developed. Lignification tends to be most intense in structural tissues such as xylem and sclerenchyma. Plant organs containing high concentrations of these tissues, such as stems, are less digestible than those containing lower concentrations. The relative proportion of lignified tissues and organs typically increases as plants mature so there is often a negative relationship between digestibility and maturity. All of these plant processes respond to environmental factors that can affect the extent and impact of lignification. Temperature, soil moisture, light, and soil fertility can have either direct or indirect effects on lignification. The most useful management practices for minimizing the negative effects of lignification are manipulation of the plant community such that it contains more desirable species and harvest management to maintain plants in a vegetative stage of development.
\end{abstract}

Key Words: Anti-quality, digestibility, forage quality, forage utilization

Lignin is considered an anti-quality component in forages because of its negative impact on the nutritional availability of plant fiber. It differs from most other classes of antiquality components in forages in that it is a structural compound rather than a

Journal Paper N. J-18367 of the Iowa Agriculture and Home Economics Experiment Station, Ames, Iowa, Project No. 2899, and supported by Hatch Act and State of Iowa.

Manuscript accepted 27 Nov. 00.

\section{Resumen}

La lignina es un polímero formado de monolignoles derivados de la vía fenilpropanoide de las plantas vasculares. Se deposita en las paredes celulares de las plantas como parte del proceso de maduración de la célula. En los forrajes, la lignina se considera como un componente anti-calidad por su impacto negativo en la disponibilidad nutricional de la fibra de la planta. La lignina interfiere con la digestión de los polisacáridos de la pared celular al actuar como barrera física para las enzimas microbianas. Por lo tanto, la lignificación tiene un impacto directo, y a menudo importante, en el valor de la energía digestible (ED) del forraje. Hay un número de factores relacionados con la planta que afectan la lignificación de las plantas individuales y de las comunidades vegetales. La lignificación esta bajo control genético y hay considerables diferencias entre especies, $y$ aun entre genotipos de la misma especie, respecto a la concentración y composición de la lignina. Las diferencias genéticas de lignificación se expresan primeramente a nivel celular y son afectadas por las actividades bioquímicas y fisiológicas de la célula. Conforme la célula se diferencia ocurren diferencias en la lignificación, dependiendo de los tejidos y orgános que se estén desarrollando. La lignificación tiende a ser mas intensa en tejidos estructurales como el xilema y esclerénquima. Los órganos de la planta que contienen altas proporciones de estos tejidos, tales como los tallos, son menos digestibles que aquellos que contienen bajas concentraciones. La proporción de tejidos y órganos lignificados típicamente aumenta conforme la planta madura, por lo que a menudo hay una relación negativa entre la digestibilidad y madurez. Todos estos procesos de la planta responden a factores ambientales que pueden afectar la cantidad e impacto de la lignificación. La temperatura, humedad del suelo, luz y fertilidad del suelo pueden tener también efectos directos o indirectos en la lignificación. Las practicas de manejo mas útiles para minimizar los efectos negativos de la lignificación son la manipulación de las comunidades vegetales para que contengan mas especies deseables y el manejo de la cosecha para mantener las plantas en estado vegetativo.

secondary metabolite. Its evolution in plants is primarily related to plant structure and function and not as a defense mechanism against other organisms. As a component of the cell wall, lignin plays an important role in morphogenesis. Cell walls form the structural framework of the plant architecture that provides mechanical support for plant organs (Varner and Lin 1989). Cell walls also are involved in water balance, ion exchange, cell 
recognition, and protection from biotic stresses (Boudet 1998, Varner and Lin 1989, Vian 1982).

Lignin is an integral component of plant cell walls. It is the last major biopolymer to have evolved within the plant kingdom and is generally regarded as the second most abundant compound, after cellulose, in the biosphere (Boudet 1998, Monties 1991). The most important function of lignin in plants is as a structural component to lend strength and rigidity to the cell wall. It is also important in limiting water loss by reducing permeability of the cell wall, and in impeding disease organisms (Dean and Eriksson 1992, Zeikus 1980). All of these attributes are desirable from the perspective of plant function and survival, but limit the nutritional value of the plant for herbivores.

Fiber is a nutritional entity which is defined as much by its biological properties as its chemical composition (Van Soest et al. 1991). With regard to forages, it has been traditionally defined as the complex of dietary nutrients that are relatively resistant to digestion and are slowly and only partially degraded by herbivores (Chesson and Forsberg 1988, Van Soest 1982). By this definition, fiber is composed of structural polysaccharides, wall proteins, and lignin. The main antiquality role of lignin in forages is in limiting digestion of the structural polysaccharides cellulose and hemicellulose (Hatfield et al. 1999, Moore and Hatfield 1994). Lignification controls the amount of fiber that can be digested and, therefore, has a direct and often important impact on the digestible energy (DE) value of the forage (Jung and Allen 1995). Lignification also influences the amount of dry matter that can be consumed by an animal (Mertens 1994). The undigested portion of the forage passes slowly through the digestive system and contributes to the fill effect of the diet. The greater the concentration of undegradable fiber in the diet the less dry matter an animal can consume. Therefore, lignification impacts forage nutritive value by both decreasing DE concentration and limiting dry matter intake (Moore et al. 1993).

In this paper we discuss the biochemistry of lignin and how it affects the digestibility of forage fiber. We also consider factors that affect lignification and therefore the quality of forages. Finally, we discuss management implications of lignin and suggest strategies for improving forage quality.

\section{Lignin Biochemistry}

While lignin has been recognized as a distinct chemical entity of plant cell walls for over 100 years (Sjostrom 1981), there is still considerable scientific argument concerning its structure, biosynthesis, and measurement. These uncertainties arise from the complexity of lignin synthesis and the resultant complexity of lignin molecules. While generalized structures for lignin have been drawn, it is not yet possible to definitely determine the complete structure of any isolated lignin molecule, let alone the structure of lignin in the plant cell wall. Because there is no standard lignin structure for reference, measurement of lignin concentration is empirical and very dependent on methodology. All of these ambiguities have made it very difficult to clarify the roles of lignin in plant growth and development, and the mechanism by which lignin limits cell wall digestibility.

Lignin can be characterized as a polymer formed from monolignols derived from the phenylpropanoid pathway in vascular plants. Recent reviews provide excellent coverage of the process and biochemistry of lignification (Baucher et al. 1998, Boudet 1998). Lignin is deposited in the cell walls of plants as part of the process of cell maturation after cell elongation has ceased. Based on difficulty of lignin extraction from the cell wall, it has been concluded that lignin is chemically linked to carbohydrates and possibly proteins in the cell wall to form large macromolecules. The only cross-linking structure of lignin to other cell-wall components that has been definitively characterized is the linkage of lignin to arabinoxylans in grasses via ferulic acid molecules (Ralph et al. 1995), although chemical extraction data does point toward $\propto$-ether linkages of lignin directly to polysaccharides (Watanabe 1989). Undoubtedly there are other lignin cross-linking structures involving both polysaccharides and proteins.

The basic pathway of lignin biosynthesis in plants is illustrated in Fig. 1. Guaiacyl-type lignin typically comprises $95+\%$ of the lignin found in gymnosperms, whereas angiosperms generally deposit significant amounts of both guaiacyl- and syringyl-type lignins. Small amounts of $p$-hydroxyphenol lignin are present in most plants. The 5-hydroxyguaiacyl-type lignin is only known to accumulate in the $b m_{3}$ (brown midrib) mutant of corn (Zea mays L.) (Lapierre et al. 1988). This particular lignin product accumulates in $b_{3}$ corn because the gene that converts 5-hydroxyferulic acid to sinapic acid is reduced in activity. As more lignin mutants and transgenic plants involving the lignin pathway have been characterized, it has become apparent that this pathway is actually more of a web than linear (Sewalt et al. 1997b). Because of this web structure and the ability of plants to incorporate non-typical phenylpropanoid precursor molecules, the results of biotechnological manipulation of the pathway have yielded unexpected results and unique lignin structures (Boudet 1998, Ralph et al. 1998). Apparently lignin plays such an important role in plant development that alternative routes and precursors can be used to provide the amount of lignin necessary for normal development. When lignin concentration has been significantly reduced through biotechnology, nonviable plants result (Jung and Ni 1998).

Deposition of lignin in the cell wall of grasses appears to involve ferulate esters of arabinoxylans as nucleation sites. In annual ryegrass (Lolium multiflorum Lam.), lignin cross-links to ferulates consisted only of structures that would form if monolignols reacted with the ferulates directly rather than polymeric lignin reacting with ferulate esters (Ralph et al. 1995). This ferulate mediated cross-linking structure is illustrated in Fig. 2. Unlike ferulic acid, $p$-coumarate (the other major cellwall hydroxycinnamic acid) in grasses does not have a lignin/polysaccharide cross-linking function and most $p$ coumarate is esterified to lignin rather than polysaccharide (Ralph et al. 1994).

Because of complex lignin structure and linkage to other cell-wall polymers, analysis of lignin concentration in forages is difficult. The standard method used in animal and agronomic sciences is the acid detergent lignin (ADL) method, of which there are sulfuric acid hydrolysis and permanganate oxidation versions of the method (Van Soest 1967, Goering and Van Soest 1970). The traditional lignin method used in wood chemistry, Klason lignin, was long believed to give inaccurate results with forages because of perceived contamination (Van Soest 1967, Lai and Sarkanen 1971). It has now been shown that the Klason lignin method does not suffer from contamination when applied to forages and that the ADL method under-estimates lignin concentration (Kondo et al. 1987, Hatfield et al. 1994, Lowry et al. 1994). This under-estimation is especially severe for grasses. The problem with the ADL method appears to be solubilization of lignin at the acid detergent fiber step of the procedure 


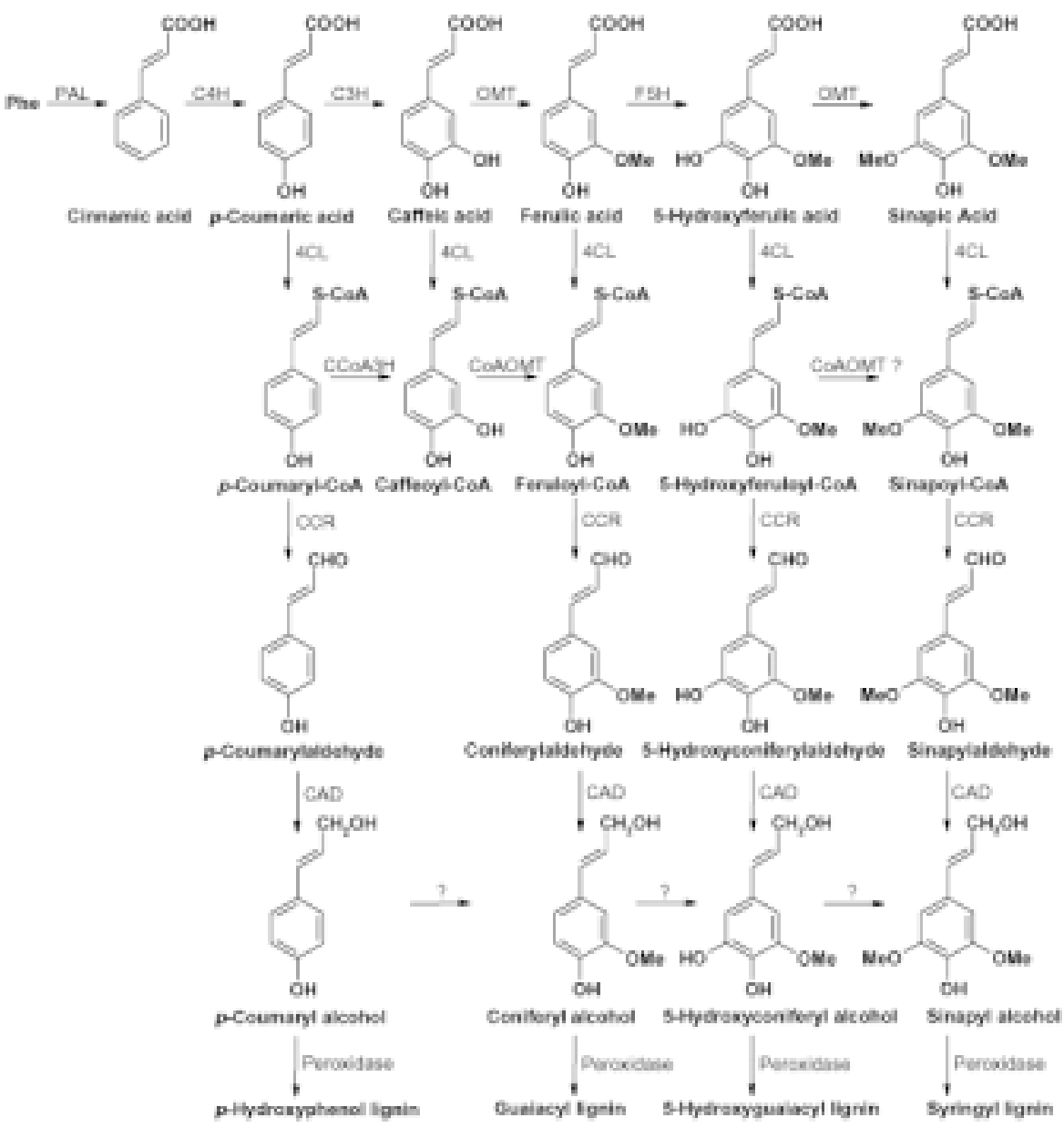

Fig. 1. A schematic representation of the lignin biosynthetic pathway starting from phenylalanine (Phe). Tyrosine is the second precursor to this pathway via tyrosine ammonia lyase to form $p$-coumaric acid. The enzymes involved in lignin synthesis include: PAL, phenylalanine ammonia lyase; $\mathrm{C} 4 \mathrm{H}$, cinnamate 4-hydroxylase; $\mathrm{C} 3 \mathrm{H}$, 4-coumaroyl hydroxylase; OMT, $O$-methyltransferase; F5H, ferulate 5-hydroxylase; 4CL, 4-coumarate-CoA ligase; $\mathrm{CCoA3H}$, 4-coumaroyl-CoA hydroxylase; CoAOMT, caffeoyl-CoA $O$-methyltransferase; CCR, cinnamoyl-CoA reductase; CAD, cinnamyl alcohol dehydrogenase, and peroxidase.

(Kondo et al. 1987, Lowry et al. 1994). Recent work indicates that Klason lignin is a much more accurate method for determining lignin concentration of forages than ADL (Jung et al. 1999). However, lignin concentration estimates from these 2 methods are positively correlated.

Analysis of the hydroxycinnamic acids in cell walls and their cross-linking to lignin involves 2 steps because these compounds are present in more than 1 structural form in the cell wall. Ferulates and $p$ coumarates that are only ester-linked to polysaccharide or lignin are extracted with alkali at room temperature (Hartley 1972, Jung and Shalita-Jones 1990). Extraction with stronger alkali at $170^{\circ} \mathrm{C}$ cleaves both ester- and ether-linked hydroxycinnamic acids (Iiyama et al. 1990). A combination of these extractions can be used to parti- for cell-wall digestion as lignin does not directly impact digestibility of plant cell solubles. The reason DM digestibility is negatively correlated with lignin concentration is because the concentration of lignin always increases as cell-wall concentration rises, and forage cell walls are always less digestible than cell solubles. The negative relationship of lignin concentration and cell-wall digestibility is true regardless of the method of lignin analysis employed and has been observed with in vivo and in vitro measures of digestibility (Jung et al. 1997). Generally, the slope of this negative relationship is less for legumes than grasses, suggesting that lignin is more inhibitory of digestion in grasses (Van Soest 1964, Buxton and Russell 1988). This conclusion has been drawn primarily from research where lignin was measured as ADL and it should be considered suspect because the ADL method under-estimates lignin concentration more severely in grasses than legumes. The opposite conclusion may in fact be true. Microscopic studies suggest that lignin may be more inhibitory in legumes than grasses because lignified legume tissues are virtually indigestible whereas thick-walled, lignified grass tissues can be digested to leave only thinwalled indigestible residues (Engels 1989, Engels and Jung 1998).

Several mechanisms have been suggested for how lignin may inhibit cell-wall digestion, however, it is now generally agreed that lignin simply acts as a physical barrier to the microbial enzymes reaching their target polysaccharides (Chesson 1993, Jung and Deetz 1993). Previous hypotheses concerning toxicity, exclusion of water-soluble enzymes due to hydrophobicity, etc. can probably be discounted. Questions still remain as to how lignin structure, cross-linkage to other cell-wall polymers, and deposition and distribution in the wall may modify the impact of lignin as a physical barrier to cell-wall digestion. This is perhaps best illustrated by the fact that while the negative relationship of lignin concentration is always observed when examined across forage samples of different maturities, when plant maturity is similar (i.e. - forages from breeding studies, corn silage, etc.) large differences in lignin concentration and cell-wall digestibility are observed but lignin and digestibility are often not correlated (Jung and Vogel 1992, Jung and Buxton 1994, Jung et al. 1994). Obviously there must be modifying factors which influence the inhibitory effect of lignin on cell-wall digestion. 


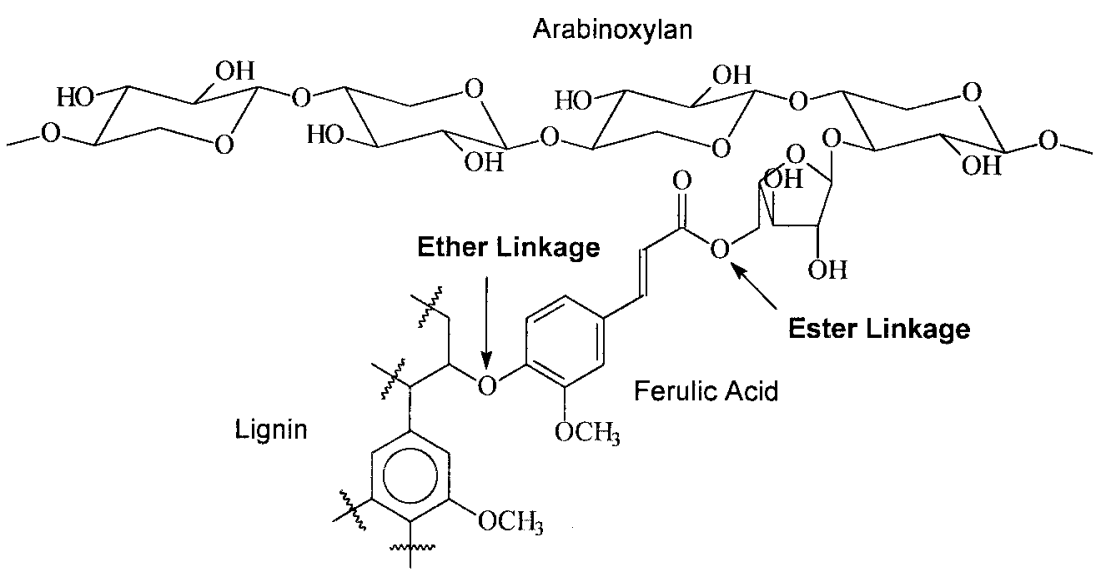

Fig. 2. Illustration of the cross-linking structure in grasses where ferulate esters of arabinoxylan form bridges to lignin. The linkage shown between lignin and ferulic acid is the 4-O- $\beta$ structure. The peroxidase $/ \mathrm{H}_{2} \mathrm{O}_{2}$ reaction which catalyzes the cross-links also yields 8-O-4, 5- $\beta, 8-5,5-5$, and 8- $\beta$ structures. The 4-O- $\beta$ linkage accounts for only about one quarter of the cross-links between feruloylarabinoxylan and lignin, but it is the only one that can be quantified because it yields intact ferulic acid after high-temperature alkaline hydrolysis (Ralph et al. 1992).

It was proposed by Jung and Deetz (1993) that lignin composition, as measured by the syringyl-to-guaiacyl lignin ratio, would alter the inhibitory impact of lignin on cell-wall digestion because $\mathrm{bm}$ mutants have more digestible cell walls and a reduced syringyl-type lignin content. However, because $\mathrm{bm}$ mutants also have less total lignin and generally slightly lower cell-wall concentrations (Cherney 1990), the $b m$ mutants are not suited to test the validity of the lignin composition hypothesis. Results from 2 transgenic tobacco (Nicotiana tabacum L.) experiments where $O$-methyltransferase and cinnamyl alcohol dehydrogenase activities were down-regulated showed improved cell-wall digestibility when the syringylto-guaiacyl lignin ratio was reduced but lignin concentration was not altered (Bernard Vailhe et al. 1996, 1998). However, no change in cell-wall digestibility was observed in an Arabidopsis thaliana [(L.) Heynh] mutant that deposits only guaiacyl-type lignin rather than the normal mixture of syringyl- and guaiacyl-type lignins (Jung et al. 1999). Obviously the impact of lignin composition on digestibility is still unresolved.

Jung and Deetz (1993) also proposed that ferulate cross-linking of lignin to polysaccharide in grasses was crucial for lignin to impede cell-wall digestion. Attempts to show negative correlations of ferulate cross-linking (measured as etherlinked ferulic acid) have met with limited success in switchgrass (Panicum virgatum L.), big bluestem (Andropogon gerardii appears likely that ferulate cross-linking of lignin to polysaccharide does influence cell-wall digestibility.

\section{Factors Affecting Lignification}

Within the greater context of forage quality there are a large number of factors that can influence the nutritive value of forage. These can be arranged into a hierarchy that indicates the relative dependence of the various levels involved (Fig. 3 ). It should be realized that all of these processes are dynamic and that there are feedback mechanisms functioning from higher to lower levels. Consequently, there are a large number of interactions that can occur which may confound attempts to sort out the effects of various factors on forage nutritive value. The effects of lignin on forage quality can be altered and, therefore, manipulated at any level in the hierarchy of factors affecting nutritive value.

Vitman), and corn (Jung and Vogel 1992, Jung and Buxton 1994). This may be because ferulate cross-links form early in grass development and subsequent deposition of lignin and cell-wall polysaccharides dilute cross-link concentrations (Morrison et al. 1998). However, using a corn cell culture model system Grabber et al. (1998) have demonstrated that reduced ferulate cross-linking will increase cellwall degradability. Recently Casler and Jung (1999) found that smooth bromegrass (Bromus inermis Leyss) genotypes selected for reduced ferulate cross-linking exhibited improved cell-wall digestibility compared to genotypes with high concentrations of ferulate ether cross-links. It

\section{Ecosystem}

The ecosystem level factors that we are concerned with in regard to forage quality are the edaphic, climatic, and biotic factors associated with a given environment that determine the potential plant communities that can be grown. The ecosystems in which forages are grown vary from the very simple to the highly complex and diverse. At one end of this spectrum are highly uniform and inherently productive environments. These can be easily manipulated through management of soil fertility, water, and pests such that the environment can be modified to a large extent to

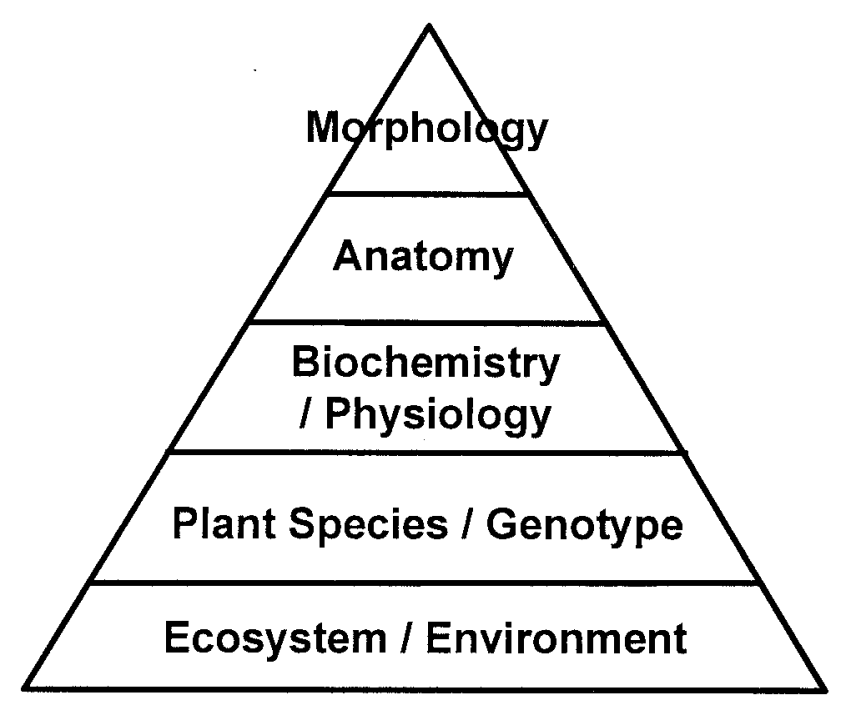

Fig. 3. Hierarchy of factors affecting forage quality. 
suit the needs of a specific and generally introduced plant community. In contrast are extremely diverse and inherently less productive environments. These environments are not easily manipulated and consequently have limited potential for modification through management. Forage production within these environments generally involves extensive management of native plant communities. Management of forage quality in these environments is generally accomplished through grazing management and to a lesser extent, other forms of vegetation management.

\section{Plant Species}

As described earlier, plant communities utilized for forage vary from simple monocultures of cultivated species to complex and diverse native plant communities. The concentration and composition of lignin varies greatly among genera, species, and, to some extent, within species comprising forage plant communities.

Nearly all important cultivated and many native forages belong to either the grass family (Poaceae) or the legume family (Fabaceae), which are of the subclasses Monocotyledonae and Dicotyledonae, respectively. There are large differences in lignification between grasses and legumes and also differences in the impact of lignin per se on their forage quality (Fig. 4). Lignin concentration of legumes often appears comparable to that of grasses when expressed as a proportion of dry matter. However, when expressed as a proportion of fiber, legumes demonstrate a wider range of lignin concentrations that are generally higher than those of grasses (Buxton and Brasche 1991, Buxton and Russell 1988). As indicated earlier, this difference may be a result of analytical problems regarding lignin measurement. The range in fiber digestibility is similar between legumes and grasses indicating that there are qualitative differences between the 2 families in the way lignin interacts with other fiber components (Buxton et al. 1987, Buxton 1989).

The most important difference between grasses and legumes is in the concentration of fiber. Grasses have much higher fiber concentrations than legumes and conversely a lower concentration of readily digestible cell contents (Buxton and Russell 1988). So even though lignin has a negative impact on the fiber digestibility of legumes, the fact that they contain much less fiber than grasses lessens its impact on overall digestible energy concentration. For these reasons, lignin concentration is not a good indicator of

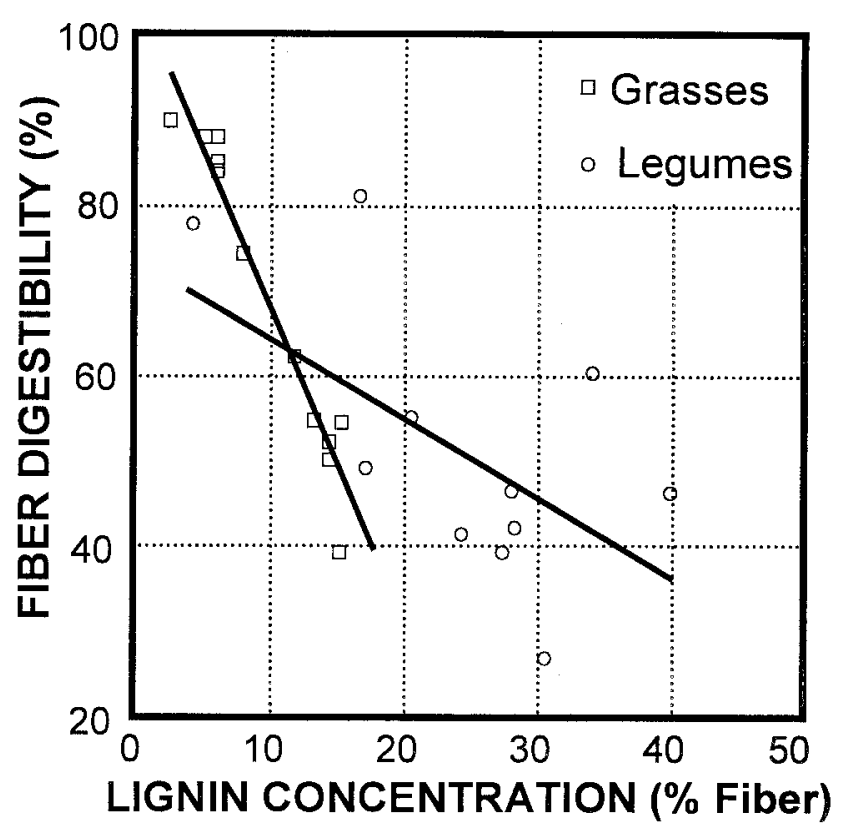

Fig. 4. Relationship between lignin concentration of fiber and fiber digestibility in legumes and grasses (Adapted from Smith et al. 1972).

digestible energy when making comparisons between grasses and legumes.

Other dicotyledonous forbs have lignins that are more similar to those of legumes than of grasses (Higuchi 1990). Most dicotyledonous shrubs and trees have relatively high lignin concentrations and concomitantly low fiber digestibility. This is reflection of the fact that they contain more heavily lignified tissues than do herbaceous species. The foliage of some browse species, however, can often be quite digestible (Chriyaa et al. 1997).

Cool-season and warm-season grasses have similar lignin and fiber composition (Jung and Vogel 1986, 1992). The primary distinction between cool- and warm-season grasses is that warm-season species generally have higher fiber and, therefore, higher lignin concentrations at comparable growth stages. Anatomical differences between cool- and warm-season grasses appear to account for most of the difference in fiber composition between the 2 types of grasses (Akin 1989). Warm-season grasses partition more dry matter into lignified tissues with thickened secondary walls.

Even within a single species or cultivar there may be significant genotypic differences in lignification since many forage cultivars are synthetic populations (Casler and Vogel 1999, Vogel and Pedersen 1993). These differences provide the genetic variability necessary to make improvements in the forage quality of these species through traditional breeding approaches. There are several examples of improvement in forage quality through either direct or indirect modification of lignin by breeding. Selection for decreased lignin in alfalfa (Medicago sativa $\mathrm{L}$.) on a whole-plant basis resulted in changes in both fiber concentration and plant morphology (Kephart et al. 1989, 1990). Alfalfa lines selected for low lignin had shorter stems, higher leaf to stem ratios and higher concentrations of fiber in stem bases than high lignin lines. This selection for lower acid detergent lignin in alfalfa resulted in variable and inconsistent effects with respect to improving fiber digestibility (Jung et al. 1994).

Improvements made by selection for high dry matter digestibility in grasses have been related to changes in lignification in some cases. In smooth bromegrass, selection for improved dry matter digestibility was correlated with changes in lignification (Casler and Carpenter 1989, Jung and Casler 1990) and it was concluded that there may be some potential for improving digestibility by selection for low lignin. However, in switchgrass, substantial improvements in dry matter digestibility have been made without changing either the concentration of fiber or lignin (Moore et al. 1993). Selection for high digestibility has resulted in changes in fiber digestibility independent of lignin concentration, but may be related to how lignin interacts with the cell-wall polysaccharides (Gabrielson et al. 1990).

Ploidy level has been demonstrated to have an impact on lignin concentration of 
forage grasses. In Brachiaria, lignin concentration was higher in tetraploid than in diploid accessions (do Valle et al. 1988). However, there were no differences in fiber digestibility among the ploidy levels. In Napiergrass (Pennisetum purpureum Schumach.), differences in morphology were observed among triploid, tetraploid, and hexaploid lines, but the chemical compositions of various morphological structures were similar (Schank and Chynoweth 1993).

\section{Biochemistry and Physiology}

Genotypic differences among forages are initially expressed at the biochemical level in response to environmental stimuli. The biosynthesis of lignin as described earlier is a complex process involving a number of enzyme-mediated reactions (Boudet 1998). Lignin concentration and composition is regulated by these enzymes and can be altered by attenuating their activities (Dixon et al. 1996).

A well-known example of biochemically altered lignin is the $b m$ mutation. The bm mutation is characterized by darkened coloration of the leaf mid vein and usually is related to lowered concentrations and altered composition of lignin (Cherney et al. 1991). It occurs naturally in corn and has been induced through mutagenesis in sorghum (Sorghum bicolor (L.) Moench.) (Fritz et al. 1981, Porter et al. 1978) and pearlmillet (Pennisetum americanum (L.) Leeke)(Cherney et al. 1988). The phenotypic effects of $\mathrm{bm}$ mutations have been well characterized (Fritz et al. 1990, Gerhardt et al. 1994, Moore et al. 1989) and have been related to altered enzyme activities (Bucholtz et al. 1980, Grand et al. 1985). The $b m$ trait is of particular interest in forages because it is usually associated with relatively significant increases in fiber digestibility (Akin et al. 1986, Cherney et al. 1991, Wedig et al. 1987). Commercial varieties of $\mathrm{bm}$ corn and sorghum have been developed and have been demonstrated to result in improved animal performance (Grant et al. 1995, Lusk et al. 1984 Weller and Phipps 1986).

Only recently, however, have the genetic mechanisms involved in $\mathrm{bm}$ mutations been studied. In the $b m_{3}$ mutant of corn, the trait has been linked to changes in the structure of the O-methyl transeferase (COMT) gene (Vignols et al. 1995). This gene codes for the enzyme that catalyzes the methylation of 5-hydroxyferulate (Boudet 1998). The mutation lowers the activity of the resulting enzyme and results in a lower lignin concentration and an altered lignin composition (Vignols et al. 1995).
Molecular geneticists have recently altered lignin biochemistry of tobacco and alfalfa using anti-sense gene modification techniques (Halpin et al. 1994, Sewalt et al. 1997b, Sewalt and Dixon 1997). Down regulating the activities of phenylalanine ammonia-lyase and cinnamate 4-hydroxylase reduced lignin concentration and resulted in improved fiber digestibility in transgenic tobacco (Sewalt et al. 1997a). In alfalfa, reducing the activities of the methylating enzymes COMT and caffeoyl-CoA O-methlytransferase resulted in only modest changes in lignin concentration and fiber digestibility (Sewalt and Dixon 1997). Molecular approaches such as these offer great promise for developing forage cultivars with improved quality characteristics (Dixon et al. 1996). However, it is unlikely that transgenic forage cultivars will be available to producers any time in the near future.

Physiological responses to several environmental factors may affect the extent of lignification that occurs within a forage plant community. Temperature, soil moisture, light, and soil fertility can have either direct or indirect effects on lignification (Buxton and Casler 1993, Nelson and Moser 1994).

Lignification tends to increase in plants grown under warmer temperatures. This appears to be related mostly to increased activities of lignin synthetic enzymes at higher temperatures (Buxton and Fales 1994), but may also be related in some instances to increased partitioning of plant dry matter to more lignified tissues (Cone and Engels 1990, da Silva et al. 1987). Wilson et al. (1991) reported that growing a number of tropical and temperate forage species under a higher temperature regime did not alter the proportion of various tissues, but rather appeared to increase the intensity of lignification. Similar results were reported for tall fescue (Festuca arundinacea Schreb.) grown under 4 temperature regimes (Akin et al. 1987). Increasing temperature did not affect leaf anatomy, but negatively affected the proportion of tissues degraded. Fales (1986) found that growing tall fescue under increasing temperatures did not affect lignification, but increased indigestible fiber concentration. Henderson and Robinson (1982) reported that increasing growth temperatures of subtropical grass species resulted in increased lignification and decreased fiber digestibility. Despite the apparent inconsistencies of the effects of temperature on lignification, the negative effect of increasing temperature on fiber digestibility appears to be consistent (Akin and Chesson 1989, Ford et al. 1979).
Moisture deficit generally decreases lignification, although this effect occurs largely as a function of changes in plant development and morphology (Buxton and Casler 1993). In alfalfa, total-cell wall concentration increased with increasing irrigation levels, but cell-wall composition was unaffected (Halim et al. 1989). Differences in forage digestibility between stressed and non-stressed plants were attributed to delayed plant maturity caused by water stress. Excess moisture can also reduce whole-plant lignin concentration. Growing alfalfa under conditions of excess moisture stunted plant development which resulted in lower concentrations of lignin and other fiber components (Buscaglia et al. 1994).

Light intensity and quality also can affect lignification of forages. Low light decreases lignification on a whole-plant basis (Buxton and Fales 1994). As with most other environmental responses, this decrease is generally related to delayed development of the plant rather than changes in lignification at the cellular level (Buxton and Casler 1993). Shaded plants tend to be less lignified (Buxton 1996). However, the effects of light intensity on lignification and fiber digestion are not always consistent. Henderson and Robinson (1982) reported that increasing light intensity had variable effects on lignification and fiber digestibility of subtropical grass species. Kephart and Buxton (1993) similarly reported that the effects of shading on lignification of a number of temperate and warm-season grasses was inconsistent, however, in their study shading consistently resulted in improved dry matter digestibility.

Light quality apparently does not impact lignification, but may influence fiber digestibility independent of lignification. Jung and Russelle (1991) grew orchardgrass (Dactylis glomerata L.) and birdsfoot trefoil (Lotus corniculatus L.) under low pressure sodium or flourescent-incandescent lights in a study designed to evaluate the effects of light quality on fiber composition and digestion independent of plant age. They found that fiber digestibility of orchardgrass decreased under sodium lamps. The effect on birdsfoot trefoil fiber digestibility was the opposite. In both cases, changes in fiber digestion were not related to changes in lignification.

Soil nutrients can have both direct and indirect effects on lignification. Deficiencies of many plant nutrients impede growth and development in a manner similar to other plant stresses (Miller and Reetz 1995). Therefore, lignification is generally reduced 
in plants growing under conditions of low soil fertility. However, there is little evidence to suggest that fertilization affects lignification when nutrient levels are adequate to support normal plant growth or that manipulating soil fertility would be a useful management tool for altering lignification.

Nitrogen fertilization has variable effects on lignification depending on plant species and the environment in which it is grown. Nitrogen fertilization had little or no impact on lignin concentration of pearlmillet stover (Powell and Fussell 1993). In alfalfa, lignin concentration was unaffected by increasing inorganic nitrogen available for plant growth (Cherney et al. 1994). Plant responses to nitrogen may be affected by other environmental factors. Collins et al. (1990) observed an increase in fiber concentration of oat (Avena sativa L.) forage with increasing nitrogen fertilizer in 1 environment, but small decreases occurred in response to nitrogen fertilizer in 3 other environments. However, lignin concentration was unaffected by fertilization. Sanderson et al. (1995) reported a significant interaction between plant density and nitrogen fertilization. In their experiment, lignin concentration increased with increasing plant density in corn fertilized with nitrogen. However, lignin concentration was unaffected by plant density in unfertilized corn.

Sulfur fertilization has been reported to decrease lignification and improve fiber digestibility in sorghum (Ahmad et al. 1995), but did not affect either lignin concentration or fiber digestibility in tall fescue or orchardgrass (Chestnut et al. 1986). It has been suggested that fiber concentration in tall fescue may be related to the ratio of nitrogen to sulfur levels available for plant growth (Sweeney and Moyer 1997). However, no such relationship occurred in corn fertilized with varying rates of nitrogen and sulfur (O'Leary and Rehm 1990).

\section{Plant Anatomy}

Lignification occurs during the process of cell differentiation and is generally coincident to secondary wall formation (Iiyama et al. 1993). Lignin deposition is initiated in the corners of the cell adjacent to the middle lamella and proceeds inward into the primary and secondary walls. Lignification is always preceded by deposition of structural carbohydrates and lags behind development of the currently developing cell wall layer. Because of this, lignin concentration is usually higher in the primary than the secondary wall. However, in cells with pronounced sec- ondary thickening the actual quantity of lignin may be higher in secondary walls due to their large volume (Terashima et al.1993, Wilson 1993).

The process of lignification occurs relatively rapidly in growing tissues. In sorghum leaf blades, lignin was present in very low concentrations in the leaf intercalary meristem, but increased dramatically to near maximum in cells adjacent to the meristem less than 1 day old (Volenec et al. 1986). Lignification in developing stems is somewhat slower. In elongating corn internodes, lignification was initiated within 2 days after elongation began and by 4 days had proceeded into all elongated tissues (Morrison and Buxton 1993).

Lignin concentration varies greatly from one cell type to another. Consequently, degradability of plant tissues is variable and related to lignin concentration. Tissues with high lignin concentrations include the epidermis (grasses), xylem, and sclerenchyma (Akin et al. 1990, Buxton and Redfearn 1997, Chesson et al. 1986, Twidwell et al. 1991). These tissues are relatively undegradable by rumen microbes (Grabber el al. 1992) and comprise a large proportion of the indigestible fraction of forages (Buxton and Redfearn 1997, Twidwell et al. 1991, Akin and Chesson 1989). Other tissues such as mesophyll and other types of parenchyma are not lignified, contain a large proportion of metabolites, and are highly degradable. Between these extremes are tissues with intermediate and variable degradability such as phloem and collenchyma (Akin 1989, Wilson 1993).

The digestibility of a forage represents the relative contributions of various plant tissues to total herbage dry matter (Magai et al. 1994). The higher the proportion of structural and other lignified tissues, the lower the digestibility of the forage (Akin 1989).

A significant proportion of the differences among species in lignin concentration and fiber digestion reflect differential partitioning among various tissues. Warmseason grasses for example, tend to have a higher proportion of lignified tissues than cool-season grasses (Akin 1989). Differences in fiber digestibility of warm-season and cool-season grasses have been related to anatomical characteristics. Warm-season grasses generally have a higher proportion of structural and other indigestible tissues than cool-season grasses (Wilson and Hattersley 1989, Wilson and Kennedy 1996).

\section{Morphology}

Lignification increases as plants mature (Brink and Fairbrother 1994, Cherney et al. 1993, Cuomo et al. 1996, Hockensmith et al. 1997). This is largely a function of changes in the morphology of the plant, and to a lesser degree, the aging of plant tissues (Anderson 1985). Changes in plant morphology are related to ontogeny (Nelson and Moser 1994). In grasses, developmental morphology is characterized by 4 primary growth stages: 1) vegetative, 2) elongation, 3) reproductive, and 4) seed ripening (Moore et al. 1991, Moore and Moser 1995). During vegetative development, the stems remain near the crown and the above ground portion of the plant consists primarily of leaves. During elongation stem internodes lengthen, increasing the proportion of stem tissue in the canopy relative to leaves. During the later 2 growth stages, inflorescences develop, fertilization occurs, and seeds develop. Development of legumes and other herbaceous dicots also occurs in vegetative and reproductive stages (Kalu and Fick 1981). During vegetative development, stem growth occurs simultaneously with leaf development. Continued cambial growth in dicot stems results in accumulation of indigestible xylem tissues. In determinate species, stem growth ceases with the onset of reproductive growth, while in indeterminate species, reproductive and vegetative growth may occur simultaneously.

As plants mature, the ratio of leaves to stems decreases (Albrecht et al. 1987, Nordkvist and Åman 1986, Martiniello et al. 1997). Because stems contain more lignified structural tissues and less metabolically active tissues than leaves, the digestibility of stems is generally much less than that of leaves (Akin 1989, Twidwell et al. 1988). Using a lignin stain and image analysis, Twidwell et al. (1991) characterized the anatomy of switchgrass leaves and stems. They reported that stems contained a greater proportion of structural and other lignified tissues than leaves and that these tissues were more resistant to degradation when incubated in buffered rumen fluid for 24 and 48 hours. Bruckner and Hanna (1990) reported similar findings in a study on the anatomy and digestibility of leaves and stems of small grain species.

Lignin concentration increases with maturity in grasses (Cherney et al. 1993, Foster et al. 1996, McBee and Miller 1993, Titgemeyer et al. 1996) and legumes (Bidlack and Buxton 1992, Kratchunov and Naydenov 1995). Quantitatively, the changes in lignification that occur as 
plants mature have the largest impact on forage quality of the factors that can be modified by forage management. In grasses, lignin concentrations more than double as plants develop from vegetative to reproductive stages of growth while in legumes, the increase is somewhat less dramatic (Albrecht et al. 1987, Bidlack and Buxton 1992, Brink and Fairbrother 1994).

\section{Management Implications}

The goal of managing forage quality is not necessarily to minimize lignin concentration, but rather to minimize its impacts on fiber digestion and intake. To some extent, management can be used to manipulate lignification and its impact on fiber digestion at each of the levels discussed in the previous section (Fig. 3). However, from a practical perspective, the most useful management practices for this purpose are manipulation of the plant community such that it contains more desirable (less lignified and more digestible) plants, harvest management to maintain plants in a vegetative state of development, and when necessary, postharvest treatments to improve the digestibility of low quality harvested forages.

Species and variety selection are extremely useful tools for managing forage quality within the constraints of an ecosystem. Obviously, other factors such as yield, seasonal growth distribution, and establishment and production costs may be as or more important than forage quality. However, altering species composition, either by seeding or vegetation manipulation, can greatly enhance the yield of available nutrients and productivity of the system. The goal is to develop a plant community with inherently high quality characteristics.

Establishment of improved cultivars of adapted species can enhance productivity of forage-livestock systems and increase economic returns. Studies have demonstrated substantial improvements in the performance of beef cattle grazing pastures with improved forage quality characteristics (Anderson et al. 1988, Moore et al. 1995). Estimates in the value of increased production realized from improvements in forage quality range from $\$ 50$ to $\$ 85$ per hectare per year (Vogel and Sleper 1994).

Defoliation management is probably the most powerful tool available to producers for managing forage quality. Timing of harvest and grazing events such that forages are maintained in a vegetative state is the most effective and straightforward approach to managing the decline in forage quality associated with plant maturity
(Hirschfeld et al. 1996, Norton et al. 1997). Again, decisions with regard to defoliation management need to be weighed against other factors such as yield and effects on plant persistence. In addition to defoliation, maturation of forages can be controlled by burning, clipping, and application of plant growth regulators (Mitchell et al. 1996, Roberts and Moore 1990). However, none of these other treatments has the impact of properly timed defoliation.

There are a number of postharvest treatments that can be used to improve the digestibility of fiber in highly lignified forages. These have been reviewed in some detail by Fahey et al. (1993). There are 4 basic strategies employed in postharvest treatments that have been developed to lessen the impact of lignin on fiber digestion. These include alkaline hydrolysis, enzymatic hydrolysis, oxidation, and microbial treatments. Of these, alkaline hydrolysis is by far the most common and practical.

Alkaline treatments have been demonstrated to improve the digestibility of grasses, but not legumes. The reagents most commonly used for this purpose are ammonia and various hydroxides (Fahey et al. 1993). Ammoniation of forages can be accomplished using anhydrous ammonia applied in gaseous form or by incorporating urea with the forage (Fritz et al. 1991, Moore et al. 1985, Sewalt et al. 1996). Ammoniation increases fiber digestibility and crude protein concentration whereas treatment with sodium hydroxide only increases fiber digestion, however, sodium hydroxide treatment generally results in greater increases in fiber digestibility than ammoniation. Of the alkaline treatments used to improve forage digestibility, ammoniation is the easiest to use. In all cases, chemical treatments used to enhance fiber digestion result in greater improvements when applied to poor quality roughages such as mature grasses and cereal crop residues than when applied to higher quality forages (Klopfenstein 1978).

\section{Literature Cited}

Ahmad, M.R., V.G. Allen, J.P. Fontenot, and G.W. Hawkins. 1995. Effect of sulfur fertilization on chemical composition, ensiling characteristics, and utilization by lambs of sorghum silage. J. Anim. Sci. 73:1803-1810.

Akin, D.E. 1989. Histological and physical factors affecting digestibility at forages. Agron. J. $81: 17-25$.

Akin, D.E. and A. Chesson. 1989. Lignification as the major factor limiting forage feeding value especially in warm conditions. XVI International Grassland Congress, Nice, France. p. 1753-1760.
Akin, D.E., W.W. Hanna, and L.L. Rigsby. 1986. Normal-12 and brown midrib-12 sorghum: variations in tissue digestibility. Agron. J. 78:827-832.

Akin, D.E., S.L. Fales, L.L. Rigsby, and M.E. Snook. 1987. Temperature effects on leaf anatomy, phenolic acids, and tissue digestibility in tall fescue. Agron. J. 79:271-275.

Akin, D.E., N. Ames-Gottfred, R.D. Harley, R.G. Fulcher, and L.L. Rigsby. 1990. Microspectrophotmetry of phenolic compounds in Bermudagrass cell walls in relation to rumen microbial digestion. Crop Sci. 30:396-401.

Albrecht., K.A., W.F. Wedin, and D.R. Buxton. 1987. Cell-wall composition and digestibility of alfalfa stems and leaves. Crop Sci. 27:737-741.

Anderson, B. 1985. The influence of aging on forage quality of individual switchgrass leaves and stems. p.946-949. In Proceedings of the XV Intl. Grassl. Congr.

Anderson, B., J.K. Ward, K.P. Vogel, M.G. Ward, H.J. Gorz, and F.A. Haskins. 1988. Forage quality and performance of yearlings grazing switchgrass strains selected for differing digestibility. J. Anim. Sci. 66:2239-2244.

Baucher, M., B. Monties, M. Van Montagu, and W. Boerjan. 1998. Biosynthesis and genetic engineering of lignin. Crit. Rev. Plant Sci. 17:125-197.

Bernard Vailhe, M.A., J.M. Besle, M.P. Maillot, A. Cornu, C. Halpin, and M. Knight. 1998. Effect of down-regulation of cinnamyl alcohol dehydrogenase on cell wall composition and on degradability of tobacco stems. J. Sci. Food Agr. 76:505-514.

Bernard Vailhe, M.A., C. Migne, A. Cornu, M.P. Maillot, E. Grenet, and J.M. Besle. 1996. Effect of modification of the O-methyltransferase activity on cell wall composition, ultrastructure and degradability of transgenic tobacco. J. Sci. Food Agr. 72:385-391.

Bidlack, J.E. and D.R. Buxton. 1992. Content and deposition rates of cellulose, hemicellulose, and lignin during regrowth of forage grasses and legumes. Can. J. Plant Sci. 72:809-818.

Boudet, A. M. 1998. A new view of lignification. Trends in Plant Sci. 3:67-71.

Brink, G.E. and T.E. Fairbrother. 1994. Cell wall composition of diverse clovers during primary spring growth. Crop Sci. 34:1666-1671.

Bruckner, P.L. and W.W. Hanna. 1990. In vitro digestibility of fresh leaves and stems of smallgrain species and genotypes. Crop Sci. 30:196-202.

Bucholtz, D.L., R.P. Cantrell, J.D. Axtell, and V.L. Lechtenberg. 1980. Lignin biochemistry of normal and brown midrib mutant sorghum. J. Agr. Food Chem. 28:1239-1241.

Buscaglia, H.J., H.M. Van Es, L.D. Geohring, H.C.A.M. Vermeulen, G.W. Fick, and R.F. Lucey. 1994. Alfalfa yield and quality are affected by soil hydrologic conditions. Agron. J. 86:535-542.

Buxton, D.R. 1989. In vitro digestion kinetics of temperate perennial forage legume and grass stems. Crop Sci. 29:213-219.

Buxton, D.R. 1996. Quality-related characteristics of forages as influenced by plant environment and agronomic factors. Anim. Feed Sci. Tech. 59:37-49.

Buxton, D.R. and M.R. Brasche. 1991. Digestibility of structural carbohydrates in coolseason grass and legume forages. Crop Sci. 31:1338-1345. 
Buxton, D.R. and M.D. Casler. 1993. Environmental and genetic effects on cell wall composition and digestibility. p. 685-714. In: $\mathrm{H}$ G. Jung, D. R. Buxton, R. D. Hatfield, and J. Ralph (ed.) Forage cell wall structure and digestibility. ASA-CSSA-SSSA, Madison, Wisc.

Buxton, D.R. and S.L. Fales. 1994. Plant environment and quality. p. 155-199. In G.C. Fahey, Jr., M. Collins, D.R. Mertens, and L.E. Moser (eds.) Forage quality, evaluation and utilization ASA, CSSA, and SSA, Madison, Wisc.

Buxton, D.R. and D.D. Redfearn. 1997. Plant limitations to fiber digestion and utilization. J. Nutr. 127(Suppl. 5):814-818.

Buxton, D.R. and J.R. Russell. 1988. Lignin constituents and cell-wall digestibility of grass and legume stems. Crop Sci. 28:553-558.

Buxton, D.R., J.R. Russell, W.F. Wedin. 1987. Structural neutral sugars in legume and grass stems in relation to digestibility. Crop Sci. 27:1279-1285.

Casler, M.D. and J.A. Carpenter. 1989. Morphological and chemical responses to selection for in vitro dry matter digestibility in smooth bromegrass. Crop Sci. 29:924-928.

Casler, M.D. and H.G. Jung. 1999. Selection and evaluation of smooth bromegrass clones with divergent lignin or etherified ferulic acid concentrations. Crop Sci. 39:1866-1873.

Casler, M.D. and K.P. Vogel. 1999. Accomplishments and impact from breeding for increased forage nutritional value. Crop Sci 39:12-20.

Cherney, J.H. 1990. Normal and brown-midrib mutations in relation to improved lignocellulose utilization. In: p. 205-214. D. E. Akin, et al (eds.). Microbial and Plant Opportunities to Improve Lignocellulose Utilization by Ruminants. Elsevier, New York, N.Y.

Cherney, D.J.R., J.H. Cherney, and R.F. Lucey. 1993. In vitro digestion kinetics and quality of perennial grasses as influenced by forage maturity. J. Dairy Sci. 76:790-797.

Cherney, D.J.R., J.H. Cherney, and A.N. Pell. 1994. Inorganic nitrogen supply effects on alfalfa forage quality. J. Dairy Sci. 77:230-236.

Cherney, J.H., J.D. Axtell, M.M. Hassen, and K.S. Anliker. 1988. Forage quality characterization of a chemically induced brown-midrib mutant in pearl millet. Crop Sci. 28:783-787.

Cherney, J.H., D.J.R. Cherney, D.E. Akin, and J.D. Axtell. 1991. Potential of brown-midrib, low-lignin mutants for improving forage quality. Advances in Agron. 46:157-198.

Chesson, A. 1993. Mechanistic models of forage cell wall degradation. In p. 347-376. H. G. Jung, et al. (eds.). Forage Cell Wall Structure and Digestibility. ASA-CSSA-SSSA, Madison, Wisc.

Chesson, A., and C. W. Forsberg. 1988. Polysaccharide degradation by rumen microorganisms. p. 251-284. In: P. N. Hobson (ed.) The rumen microbial system. Elsevier Applied Sci., New York, N.Y.

Chesson, A., C.S. Stewart, K. Dalgarno, and T.P. King. 1986. Degradation of isolated grass mesophyll, epidermis and fibre cell walls in the rumen by cellulolytic rumen bacteria in axenic culture. J. Appl. Bact. 60:327-336.

Chestnut, A.B., G.C. Fahey, Jr., L.L. Berger, and J.W. Spears. 1986. Effects of sulfur fertilization on composition and digestion of phenolic compounds in tall fescue and orchardgrass. J Anim. Sci. 63:1926-1934.
Chriyaa, A., K.J. Moore, and S.S. Waller. 1997. Browse foliage and annual legume pods as supplements to wheat straw for sheep. Anim. Feed Sci. and Tech. 62:85-96.

Collins, M., M.A. Brinkman, and A.A. Salman. 1990. Forage yield and quality of oat cultivars with increasing rates of nitrogen fertilization. Agron. J. 82:724-728.

Cone, J.W. and F.M. Engels. 1990. Influence of growth temperature on anatomy and in vitro digestibility of maize tissues. J. Agric. Sci. (Camb.) 114:207-212.

Cuomo, G.J., D.C. Blouin, D.L. Corkern, J.E. McCoy, and R. Walz. 1996. Plant morphology and forage nutritive value of three bahiagrasses as affected by harvest frequency. Agron. J. 88:85-89.

da Silva, J.H.S., W.L. Johnson, J.C. Burns, and C.E. Anderson. 1987. Growth and environment effects on anatomy and quality of temperate and subtropical forage species. Crop Sci. 27:1266-1273.

Dean, J.F.D. and K.E. Eriksson. 1992. Biotechnological modification of lignin structure and composition in forest trees. Holzforschung 46:135-147.

Dixon, R.A., C.J. Lamb, S. Masoud, V.J.H. Sewalt, and N.L. Paiva. 1996. Metabolic engineering: prospects for crop improvement through the genetic manipulation of phenylpropanoid biosynthesis and defense responsesa review. Gene 179:61-71.

do Valle, C.B., K.J. Moore, and D.A. Miller. 1988. Effect of ploidy level on cell wall composition and digestibility of Brachiaria ruziziensis germain et evrard. Trop. Agr. (Trinidad) 65:16-20.

Engels, F.M. 1989. Some properties of cell wall layers determining ruminant digestion. p. 80-87. In: A. Chesson and E. R. Orskov (eds.). Physico-Chemical Characterization of Plant Residues for Industrial and Feed Use. Elsevier Appl. Sci., London.

Engels, F.M., and H.G. Jung. 1998. Alfalfa stem tissues: cell-wall development and lignification. Ann. Bot. 82:561-568

Fahey, G.C., Jr., L.D. Bourquin, E.C. Titgemeyer, and D.G. Atwell. 1993. p. 715766. In H. G. Jung, D. R. Buxton, R. D. Hatfield, and J. Ralph (ed.) Forage cell wall structure and digestibility. ASA-CSSA-SSSA, Madison, Wisc.

Fales, S.L. 1986. Effects of temperature on fiber concentration, composition, and In vitro digestion kinetics of tall fescue. Agron. J. 78:963-966.

Foster, J.G., J.R. Todd, and G.W. Fissel. 1996. Quantitative measurement of fiber fractions of cool- season and warm-season grass herbage using cell-wall-degrading enzymes. J. Agr. Food Chem. 44:1475-1482.

Ford, C.W., I.M. Morrison, and J.R. Wilson. 1979. Temperature effects on lignin, hemicellulose and cellulose of tropical and temperate grasses. Aust. J. Agr. Res. 30:621-633.

Fritz, J.O., K.J. Moore and E.H. Jaster. 1990. Digestion kinetics and composition of cell walls isolated from morphological components of normal and brown midrib mutant sorghum $\mathrm{x}$ sudangrass hybrids. Crop Sci. 30:213-219.

Fritz, J.O., K.J. Moore and K.P. Vogel. 1991. Ammonia-labile bonds in high and low digestibility strains of switchgrass. Crop Sci. 31:1566-1570.
Fritz, J.O., R.P. Cantrell, V.L. Lechtenberg, J.D. Axtell, and J.M. Hertel. 1981. Brown midrib mutants in sudangrass and grain sorghum. Crop Sci. 21:706-709.

Gabrielsen, B.C., K.P. Vogel, B.E. Anderson, and J.K. Ward. 1990. Alkali-labile cell-wall phenolics and forage quality in switchgrasses selected for differing digestibility. Crop Sci. 30:1313-1320.

Gerhardt, R.L., J.O. Fritz, K.J. Moore, and E.H. Jaster. 1994. Digestion kinetics and composition of normal and brown midrib sorghum morphological components. Crop Sci. 34:1353-1361.

Goering, H.K., and P.J. Van Soest. 1970. Forage fiber analyses. USDA Agr. Handb. 379, Washington, DC.

Grabber, J.H., J. Ralph, and R.D. Hatfield. 1998. Ferulate cross-links limit the enzymatic degradation of synthetically lignified primary walls of maize. J. Agr.. Food Chem. 46:2609-2614.

Grabber, J.H., G.A. Jung, S.M. Abrams, and D.B. Howard. 1992. Digestion kinetics of parenchyma and sclerenchyma cell walls isolated from orchardgrass and switchgrass. Crop Sci. 32:806-810.

Grand, C., P. Paramentier, A. Boudet, and A.M. Boudet. 1985. Comparison of lignins and of enzymes involved in lignification in normal and brown midrib $\left(\mathrm{bm}_{3}\right)$ mutant corn seedings. Physiol. Veg. 23:905-911.

Grant, R.J., S.G. Haddad, K.J. Moore, and J.F. Pedersen. 1995. Brown midrib sorghum silage for midlactation dairy cows. J. Dairy Sci. 78:1970-1980.

Halim, R.A., D.R. Buxton, M.J. Hattendorf, and R.E. Carlson. 1989. Water-stress effects on alfalfa forage quality after adjustment for maturity differences. Agron. J. 81:189-194.

Halpin, C., M.E. Knight, G.A. Foxon, M.M. Campbell, A.M. Boudet, J.J. Boon, B. Chabbert, M.T. Tollier, and W. Schuch. 1994. Manipulation of lignin quality by downregulation of cinnamyl alcohol dehydrogenase. Plant J. 6:339-350.

Hartley, R.D. 1972. p-Coumaric and ferulic acid components of cell walls of ryegrass and their relationships with lignin and digestibility. J. Sci. Food Agr.. 23:1347-1354.

Hatfield, R.D., J. Ralph, and J.H. Grabber. 1999. Cell wall structural foundations: molecular basis for improving forage digestibilities. Crop Sci 39:27-37.

Hatfield, R.D., H.G. Jung, J. Ralph, D.R. Buxton, and P.J. Weimer. 1994. A comparison of the insoluble residues produced by the Klason lignin and acid detergent lignin procedures. J. Sci. Food Agr.. 65:51-58.

Henderson, M.S., and D.L. Robinson. 1982. Environmental influences on yield and In vitro true digestibility of warm-season perennial grasses and the relationships to fiber components. Agron. J. 74:943-946.

Higuchi, T. 1990. Lignin biochemistry: biosynthesis and biodegradation. Wood Sci. Technol. 24:23-63.

Hirschfeld,D.J., D.R. Kirby, J.S. Caton, S.S Silcox, and K.C. Olson. 1996. Influence of grazing management on intake and composition of cattle diets. J. Range Manage. 49:257-263.

Hockensmith, R.L., C.C. Sheaffer, G.C. Marten, and J.L. Halgerson. 1997. Maturation effects on forage quality of Kentucky bluegrass. Can. J. Plant Sci. 77:75-80. 
Iiyama, K., T.B. T. Lam, and B.A. Stone. 1990. Phenolic acid bridges between polysaccharides and lignin in wheat internodes. Phytochem. 29:733-737.

Iiyama, K., T.B.T. Lam, P.J. Miekle, K. Ng, D.I. Rhodes, and B.A. Stone. 1993. Cell wall biosynthesis and its regulation. p. 621-683. In: H. G. Jung, D. R. Buxton, R. D. Hatfield, and J Ralph (ed.) Forage cell wall structure and digestibility. ASA-CSSA-SSSA, Madison, Wisc.

Jung, H.G. and M.S. Allen. 1995. Characteristics of plant cell walls affecting intake and digestibility of forages by ruminants. J. Anim. Sci. 73:2774-2790.

Jung, H. G. and D. R. Buxton. 1994. Forage quality variation among maize inbreds: relationships of cell-wall composition and in vitro degradability for stem internodes. J. Sci. Food Agr. 66:313-322.

Jung, H.G. and M.D. Casler. 1990. Lignin concentration and composition of divergent smooth bromegrass genotypes. Crop Sci. 30:980-985.

Jung, H.G. and D.A. Deetz. 1993. Cell wall lignification and degradability. p. 315-346. In H. G. Jung, et al. (eds.). Forage Cell Wall Structure and Digestibility. ASA-CSSA-SSSA, Madison, Wisc.

Jung, H.G. and W. Ni. 1998. Lignification of plant cell walls: impact of genetic manipulation Proc. Natl. Acad. Sci. USA 95:12742-12743.

Jung, H.G. and M.P. Russelle. 1991. Light source and nutrient regime effects on fiber composition and digestibility of forages. Crop Sci. 31:1065-1070

Jung, H.G. and S.C. Shalita-Jones. 1990. Variation in the extractability of esterified $\mathrm{p}$ coumaric and ferulic acids from forage cell walls. J. Agr. Food Chem. 38:397-402.

Jung, H.G. and K.P. Vogel. 1986. Influence of lignin on digestibility of forage cell wall material. J. Anim. Sci. 62:1703-1712.

Jung, H.G. and K.P. Vogel. 1992. Lignification of switchgrass (Panicum virgatum) and big bluestem (Andropogon gerardii) plant parts during maturation and its effect on fiber degradability. J. Sci. Food Agr. 59:169-176.

Jung, H.G., D.R. Mertens, and A.J. Payne. 1997. Correlation of acid detergent lignin and Klason lignin with digestibility of forage dry matter and neutral detergent fiber. J. Dairy Sci. 80:1622-1628.

Jung, H.G., R.R. Smith, and C.S. Endres. 1994 Cell wall composition and degradability of stem tissue from lucerne divergently selected for lignin and in vitro dry-matter disappearance. Grass Forage Sci. 49:295-304.

Jung, H.G., W. Ni, C.C.S. Chapple, and K. Meyer. 1999. Impact of lignin composition on cell-wall degradability in an Arabidopsis mutant. J. Sci. Food Agr. 79:922-928.

Jung, H.G., V.H. Varel, P.J. Weimer, and J. Ralph. 1999. Accuracy of Klason lignin and acid detergent lignin methods assessed by bomb calorimetry. J. Agr. Food Chem. 47:2005-2008

Kalu, B.A. and G.W. Fick. 1981. Quantifying morphological development of alfalfa for studies of herbage quality. Crop Sci. 21:267-271.

Kephart, K.D. and D.R. Buxton. 1993. Forage quality responses of $\mathrm{C}_{3}$ and $\mathrm{C}_{4}$ perennial grasses to shade. Crop Sci. 33:831-837.

Kephart, K.D., D.R. Buxton, and R.R. Hill, Jr 1989. Morphology of alfalfa divergently selected for herbage lignin concentration. Crop. Sci. 29:778-782.
Kephart, K.D., D.R. Buxton, and R.R. Hill, Jr. 1990. Digestibility and cell-wall components of alfalfa following selection for divergent herbage lignin concentration. Crop Sci. 30:207-212.

Klopfenstein, T. 1978. Chemical treatment of crop residues. J. Anim. Sci. 46:841-848.

Kondo, T., K. Mizuno, and T. Kato. 1987. Variation in solubilities of lignin in acid detergent and in alkali. J. Japan. Grassl. Sci. 33:296-299.

Kratchunov, I. and T. Naydenov. 1995. Estimation of lucerne forage quality by means of morphological and meteorological data. Eur. J. Agron. 4:263-267.

Lai, Y.Z. and K.V. Sarkanen. 1971. Isolation and structural studies. p. 165-240. In K. V. Sarkanen and C. H. Ludwig (eds.). Lignins: Occurrence, Formation, Structure and Reactions. Wiley-Interscience, New York, N.Y.

Lapierre, C., M.T. Tollier, and B. Monties. 1988. Occurrence of additional monomeric units in the lignins from internodes of a brownmidrib mutant of maize $b_{3}$. C. R. Acad. Sci. Paris 307:723-728.

Lowry, J.B., L.L. Conlan, A.C. Schlink, and C.S. McSweeney. 1994. Acid detergent dispersible lignin in tropical grasses. J. Sci. Food Agr. 65:41-49.

Lusk, J.W., P.K. Karau, D.O. Balogu, and L.M. Gourley. 1984. Brown midrib sorghum or corn silage for milk production. J. Dairy Sci. 67:1739-1744.

Magai, M.M., D.A. Sleper, and P.R. Beuselinck. 1994. Degradation of three warm-season grasses in a prepared cellulase solution. Agron. J. 86:1049-1053.

McBee, G.G. and F.R. Miller. 1993. Stem carbohydrate and lignin concentrations in sorghum hybrids at seven growth stages. Crop Sci. 33:530-534.

Martiniello, P., R. Paolette, N. Berardo. 1997. Effect of phenological stages on dry matter and quality components in lucerne. European J. Agron. 6:79-87.

Mertens, D.R. 1994. Regulation of forage intake. p. 450-493. In G. C. Fahey, Jr. (ed.) Forage Quality, Evaluation, and Utilization. ASA, CSSA, SSSA, Madison, Wisc.

Miller, D.A. and H.F. Reetz, Jr. 1995. Forage fertilizer. p. 71-87. In R. F. Barnes, D. A. Miller, and C. J. Nelson (eds.) Forages: An Introduction to Grassland Agriculture, 5th ed, Vol. I. Iowa State University Press, Ames, Iowa.

Mitchell, R. B., R. A. Masters, S. S. Waller, K. J. Moore, and L. J. Young. 1996. Tallgrass prairie vegetation response to burning date, fertilizer, and atrazine. J. Range Manage. 49:131-136.

Monties, B. 1991. Plant cell walls as fibrous lignocellulosic composites: Relations with lignin structure and function. Anim. Feed Sci. Tech. 32:159-175.

Moore, K.J. and R.D. Hatfield. 1994. Carbohydrates and forage quality. p. 229-280. In G. C. Fahey, Jr. (ed.) Forage Quality, Evaluation, and Utilization. ASA, CSSA, SSSA, Madison, Wisc.

Moore, K.J. and L.E. Moser. 1995. Quantifying developmental morphology of perennial grasses. Crop Sci. 35:37-43.

Moore, K.J., J.O. Fritz, and E.H. Jaster. 1989. In situ degradation of cell wall neutral sugars of normal and brown midrib sorghum $\mathrm{x}$ sundangrass hybrids. XVI International Grassland Congress, Nice, France. p. 929-930.
Moore, K. J., V. L. Lechtenberg and K. S. Hendrix. 1985. Quality of orchardgrass hay ammoniated at different rates, moisture concentrations, and treatment durations. Agron. J. 77:67-71.

Moore, K. J., K. P. Vogel, T. J. Klopfenstein, and B. E. Anderson. 1995. Evaluation of four intermediate wheatgrass populations under grazing. Agron. J. 87:744-747

Moore, K. J., K. P. Vogel, A. A. Hopkins, J. F. Pedersen, and L. E. Moser. 1993. Improving the digestibility of warm-season perennial grasses. Proc. XVI International Grassland Congr., p. 447-448.

Moore, K.J., L.E. Moser, K.P. Vogel, S.S. Waller, B.E. Johnson, and J.F. Pedersen. 1991. Describing and quantifying growth stages of perennial forage grasses. Agron. J. 83:1073-1077.

Morrison, T.A. and D.R. Buxton. 1993. Cell wall phenolic content in tissue types of developing maize internodes. p. 1097-1099. In: Proc. $17^{\text {th }}$ Internat. Grassl. Congr, Palmerston North, New Zealand. 13-16 February 1993. SIR Publ, Wellington, New Zealand.

Morrison, T.A., H.G. Jung, D.R. Buxton, R.D. Hatfield. 1998. Cell-wall composition of maize internodes of varying maturity. Crop Sci. 38:455-460.

Nelson, C.J. and L.E. Moser. 1994. Plant factors affecting forage quality. p. 115-154. In: G. C. Fahey, Jr. (ed.) Forage Quality, Evaluation, and Utilization. ASA, CSSA, SSSA, Madison, Wisc.

Nordkvist, E. and P. Åman. 1986. Changes during growth in anatomical and chemical composition and in-vitro degradability of lucerne. J. Sci. Food Agr. 37:1-7.

Norton, N.A. R.T. Clark, P.E. Reece,and K.M Eskridge. 1997. Quality as a factor in the optimal choice of fertilization and harvest date of meadow hay. J. Prod. Agr. 10:551-557.

O'Leary, J.J., and G.W. Rehm. 1990. Nitrogen and sulfur effects on the yield and quality of corn grown for grain and silage. J. Prod. Agr. 3:135-140.

Porter, K.S., J.D. Axtell, V.L. Lechtenberg, and V.F. Colenbrander. 1978. Phenotype, fiber composition, and in vitro dry matter disappearance of chemically induced brown midrib ( $\mathrm{bmr}$ ) mutants of sorghum. Crop Sci. 18:205-208.

Powell, J.M. and L.K. Fussell. 1993. Nutrient and structural carbohydrate partitioning in pearl millet. Agron. J. 85:862-866.

Ralph, J., J.H. Grabber, and R.D. Hatfield. 1995. Lignin-ferulate cross-links in grasses: active incorporation of ferulate polysaccharide esters into ryegrass lignins. Carbohydrate Res. 275:167-178.

Ralph, J., R.F. Helm, S. Quideau, and R.D. Hatfield. 1992. Lignin-feruloyl ester cross-links in grasses. Part 1. Incorporation of feruloyl esters into coniferyl alcohol dehydrogenation polymers. J. Chem. Soc. Perkin Trans. 1:2961-2969.

Ralph, J., R.D. Hatfield, S. Quideau, R.F. Helm, J.H. Grabber, and H.G. Jung. 1994. Pathway of p-coumaric acid incorporation into maize lignin as revealed by NMR. J. Amer. Chem. Soc. 116:9448-9456.

Ralph, J., R.D. Hatfield, J. Piquemal, N. Yahiaoui, M. Pean, C. Lapierre, and A.M. Boudet. 1998. NMR characterization of altered lignins extracted from tobacco plants down-reg- 
ulated for lignification enzymes CAD and CCR Proc. Natl. Acad. Sci. USA 95:12803-12808.

Roberts, C. A. and K. J. Moore. 1990. Chemical regulation of tall fescue growth and quality. Agron. J. 82:523-526.

Sanderson, M.A., R.M. Jones, J.C. Read, and H. Lippke. 1995. Digestibility and lignocellulose composition of forage corn morphological components. J. Prod. Agr. 8:169-174.

Scalbert, A., B. Monties, J.Y. Lallemand, E. Guittet, and C. Rolando. 1985. Ether linkage between phenolic acids and lignin fractions from wheat straw. Phytochem. 24:1359-1362.

Schank, S.C. and D.P. Chynoweth. 1993. The value of triploid, tetraploid, and hexaploid napier grass derivatives as biomass and (or) forage. Trop. Agr. (Trinidad) 70:83-87.

Sewalt, V.J.H. and R.A. Dixon. 1997. Genetic engineering of lignin as a means to improve nutritive quality of forages. In 1997 American Forage and Grassland Council Proceedings. April 13-15, 1997, Fort Worth, Tex.

Sewalt, V.J.H., J.P. Fontenot, V.G. Allen, and W.G. Glasser. 1996. Fiber composition and in vitro digestibility of corn stover fractions in response to ammonia treatment. J. Agr. Food Chem. 44:3136-3142.

Sewalt, V.J.H., W. Ni, H.G. Jung, and R.A. Dixon. 1997a. Lignin impact on fiber degradation: increased enzymatic digestibility of genetically engineered tobacco (Nicotiana tabacum) stems reduced in lignin content. J. Agr. Food Chemistry 45:1977-1983.

Sewalt, V.J.H, N. Weiting, J.W. Blount, H.G. Jung, S.A. Masourd, P.A. Howles, C. Lamb, and R.A. Dixon. 1997b. Reduced lignin content and altered lignin composition in transgenic tobacco down-regulated in expression of 1 phenylalanine ammonia-lyase or cinnamate 4hydroxylase. Plant Physiol. 115:41-50.

Sjostrom, E. 1981. Wood chemistry. Academic Press, New York, N.Y. p. 223.

Smith, L. W., H. K. Goering, and C. H. Gordon. 1972. Relationships of forage composition with rates of cell wall digestion and indigestibility of cell walls. J. Dairy Sci. 55:1140-1147.

Sweeney, D. W., and J. L. Moyer. 1997. Sulfur source and placement effects on forage yield and quality of established tall fescue. Agron J. 89:905-910.
Terashima, N., K. Fukushima, L-F. He, and K. Takabe. 1993. Comprehensive model of the lignified plant cell wall. p. 247-270. In: H. G. Jung, D. R. Buxton, R. D. Hatfield, and J. Ralph (ed.) Forage cell wall structure and digestibility. ASA-CSSA-SSSA, Madison, Wisc.

Titgemeyer, E.C., R.C. Cochran, E.G. Towne, C.K. Armendariz, and K.C. Olson. 1996. Elucidation of factors associated with the maturity-related decline in degradability of big bluestem cell wall. J. Anim. Sci. 74:648-657.

Twidwell, E.K., K.D. Johnson, J.H. Cherney, and J.J. Volenec. 1988. Forage quality and digestion kinetics of switchgrass herbage and morphological components. Crop Sci. 28:778-782.

Twidwell, E.K., K.D. Johnson, J.A. Patterson, J.H. Cherney, and C.E. Bracker. 1991. Degradation of switchgrass anatomical tissue by rumen microorganisms. Crop Sci. 30:1321-1328.

Van Soest, P.J. 1964. Symposium on nutrition and forage and pastures: New chemical procedures for evaluating forages. J. Anim. Sci. 23:838-845.

Van Soest, P.J. 1967. Development of a comprehensive system of feed analysis and its application to forages. J. Anim. Sci. 26:119-128.

Van Soest, P.J. 1982. Nutritional ecology of the ruminant. O and B Books, Inc., Corvalis, Ore.

Van Soest, P.J., J.B. Robertson, and B.A. Lewis. 1991. Methods for dietary fiber, neutral detergent fiber, and nonstarch polysaccharides in relation to animal nutrition. J. Dairy Sci. 74:3583-3597.

Varner, J.E. and L.-S. Lin. 1989. Plant cell wall architecture. Cell 56:231-239.

Vian, B. 1982. Organized microfibril assembly in higher plant cells. p. 23-43. In: R. M. Brown, Jr. (ed.) Cellulose and other natural polymer systems. Plenum Publishing Corp, New York, N.Y.

Vignols, F., J. Rigau, M.A. Torres, M. Capellades, and P. Puigdomenech. 1995. The brown midrib3 (bm3) mutation in maize occurs in the gene encoding caffeic acid O-methyltransferase. Plant Cell 7:407-416.

Vogel, K.P. and J.F. Pedersen. 1993. Breeding systems for cross-pollinated perennial grasses. Plant Breeding Rev. 11:251-274.
Vogel, K.P. and D.A. Sleper. 1994. Alteration of plants via genetics and plant breeding. p. 891-921. In: G. C. Fahey, Jr. (ed.) Forage Quality, Evaluation, and Utilization. ASA, CSSA, SSSA, Madison, Wisc.

Volenec, J.J., J.H. Cherney, and K.J. Moore. 1986. Rate of synthesis of cell wall components in sorghum leaf blades. Crop Sci. 26:307-311.

Watanabe, T. 1989. Structural studies on the covalent bonds between lignin and carbohydrate in lignin-carbohydrate complexes by selective oxidation of the lignin with 2,3-dichloro-5,6dicyano-1,4-benzoquinone. Wood Res. 76:59-123.

Wedig, C.L., E.H. Jaster, K.J. Moore and N.R. Merchen. 1987. Rumen turnover and digestion of normal and brown midrib sorghum $\mathrm{x}$ sudangrass hybrid silages in dairy cattle. J. Dairy Sci. 70:1220-1227.

Weller, R.F. and R.H. Phipps. 1986. The feeding value of normal and brown midrib-3 maize silage. J. Agr. Sci. 106:31-35.

Wilson, J.R.. 1993. Organization of forage plant tissues. p. 1-32. In: H. G. Jung, D. R. Buxton, R. D. Hatfield, and J. Ralph (ed.) Forage cell wall structure and digestibility. ASA-CSSASSSA, Madison, Wisc.

Wilson, J.R. and P.W. Hattersley. 1989. Anatomical characteristics and digestibility of leaves of Panicum and other grass genera with $\mathrm{C}_{3}$ and different types of $\mathrm{C}_{4}$ photosynthetic pathway. Aust. J. Agr. Res. 40:125-136.

Wilson, J.R. and P.M. Kennedy. 1996. Plant and animal constraints to voluntary feed intake associated with fibre characteristics and particle breakdown and passage in ruminants. Aust. J. Agr. Res. 47:199-225.

Wilson, J.R., B. Deinum, and F.M. Engels. 1991. Temperature effects on anatomy and digestibility of leaf and stem of tropical and temperate forage species. Netherlands J. Agr. Sci. 39:3-48.

Zeikus, J.G. 1980. Fate of lignin and related aromatic substrates in anaerobic environments. $p$. 101-109. In: T. K. Kirk et al. (ed.) Lignin biodegradation: Microbiology, chemistry, and potential applications, Vol. 1. CRC Press, Boca Raton, La. 